\title{
PERBAIKAN INSTALASI LISTRIK DAN PEMASANGAN SAKLAR OTOMATIS PHOTO CONTROL SENSOR LAMPU PENERANGAN DI MASJID RIYADUS SOLIHIN KAMPUNG KEBON DUREN RT 03 / RW 04 KELURAHAN KALIMULYA KECAMATAN CILODONG KOTA DEPOK
}

\author{
Asep Yana $Y^{1} \boxminus$, Arifia Eka $Y^{2}$, Agus Sukandi ${ }^{3}$ \\ ${ }^{1,2,3}$ Program Studi Teknik Konversi Energi Jurusan Teknik Mesin, Politeknik Negeri Jakarta \\ Alamat: Jl. Prof. DR. G.A. Siwabessy, Kampus Universitas Indonesia Depok 16425 \\ $\nabla_{e-m a i l:}$ mesin@pnj.ac.id
}

\begin{abstract}
The title of Community Service Activities is "Repair of Electrical Installations and Installation of Automatic Switches for Photo Control Light Sensors at the Riyadus Solihin Mosque, Kebon Duren Village RT 03 / RW 04 Kelurahan Kalimulya Cilodong District, Depok City." This activity is based on the aim of improving public facilities and infrastructure, in this case the Riyadus Solihin Mosque in the electricity sector to support religious activities carried out by the surrounding community. This activity will provide education to the surrounding community about the importance of maintaining the safety of lighting electrical installations and the use of energy-efficient lamps through repairing damaged electrical installations and installing energy-saving automatic switches. The expected results with the repair of electrical installations will contribute to the safety and tidiness of electrical installations with maintained continuity. In addition, this activity also carried out the installation of an automatic light switch that functions to turn on and turn off the lighting so that it will save electrical energy in an era where the economic needs of society are increasing today.
\end{abstract}

Keywords-- Repair, electrical installation, Riyadus Solihin Mosque

\begin{abstract}
Abstrak
Judul Kegiatan Pengabdian kepada Masyarakat adalah "Perbaikan Instalasi Listrik dan Pemasangan Saklar Otomatis Photo Control Sensor Lampu Penerangan di Masjid Riyadus Solihin Kampung Kebon Duren RT 03 / RW 04 Kelurahan Kalimulya Kecamatan Cilodong Kota Depok.” Kegiatan ini didasari dengan tujuan untuk memperbaiki sarana dan prasarana fasilitas umum, dalam hal ini Masjid Riyadus Solihin di bidang kelistrikan untuk menunjang kegiatan keagamaan yang dilaksanakan masyarakat sekitar. Pada kegiatan ini akan dilakukan edukasi kepada masyarakat sekitar tentang pentingnya memelihara keamanan instalasi listrik penerangan serta penggunaan lampu yang hemat energi melalui kegiatan perbaikan instalasi listrik yang rusak dan pemasangan saklar otomatis hemat energi. Hasila yang diharapkan dengan perbaikan instalasi listrik akan berkontribusi terhadap keamanan dan kerapian instalasi listrik dengan kontinuitas yang terjaga. Selain itu, pada kegiatan ini juga dilakukan pemasangan saklar lampu otomatis yang berfungsi untuk menyalakan dan mematikan lampu penerangan sehingga akan menghemat energi listrik di zaman yang semakin meningkatnya kebutuhan ekonomi masyarakat seperti sekarang ini.
\end{abstract}

Kata Kunci - Perbaikan, instalasi listrik, Masjid Riyadus Solih 


\section{Pendahuluan}

Program Studi Teknik Konversi Energi, Jurusan Teknik Mesin telah melaksanakan Program Pengabdian Kepada Masyarakat dengan Judul "Perbaikan Instalasi Listrik dan Pemasangan Saklar Otomatis Photo Control Sensor Lampu Penerangan di Masjid Riyadus Solihin Kampung Kebon Duren RT 03 / RW 04 Kelurahan Kalimulya Kecamatan Cilodong Kota Depok." Kegiatan ini didasari dengan tujuan untuk memperbaiki sarana dan prasarana fasilitas umum, dalam hal ini Masjid Riyadus Solihin di bidang kelistrikan untuk menunjang kegiatan keagamaan yang dilaksanakan masyarakat sekitar. Pada kegiatan ini akan dilakukan edukasi kepada masyarakat sekitar tentang pentingnya memelihara keamanan instalasi listrik penerangan serta penggunaan lampu yang hemat energi melalui kegiatan perbaikan instalasi listrik yang rusak dan pemasangan saklar otomatis hemat energi.

Wilayah RT.03/04 Kampung Kebon Duren Kelurahan Kalimulya Kecamatan Cilodong Kota Depok memiliki sarana tempat ibadah yang merupakan fasum (fasilitas umum) yang digunakan untuk beribadah dan berinteraksi khususnya umat Muslim, yaitu Masjid Riyadus Solihin. Berdasarkan hasil survey, Masjid Riyadus Solihin yang berada di Wilayah RT.03/04 Kampung Kebon Duren Kelurahan Kalimulya Kecamatan Cilodong Kota Depok mengalami kerusakan di bidang kelistrikan, antara lain saklar banyak yang rusak, kabel instalasi yang semrawut dan banyak sambungan disana sini, dan lampu penerangan yang kurang terang sehingga mengganggu kegiatan ibadah.Keamanan dan kerapian instalasi listrik dalam suatu fasilitas umum merupakan hal yang sangat penting dalam menunjang sarana dan prasarana fasilitas umum tersebut.

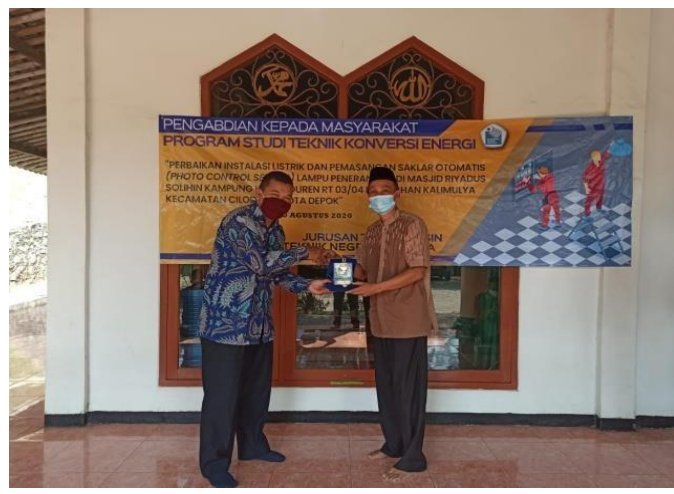

Gambar 2. Foto Bersama

Masjid merupakan salah satu fasilitas umum untuk warga melaksanakan kegiatan keagamaan, sehingga instalasi listrik yang aman dan rapi merupakan hal yang wajib menjadi perhatian pihak pengelola masjid. Selain itu, pada bidang kelistrikan saat ini sedang dianjurkan untuk menggunakan lampu yang hemat energi listrik. Hal tersebut dapat dilaksanakan melalui pemasangan saklar otomatis lampu penerangan dengan photo control sensor.

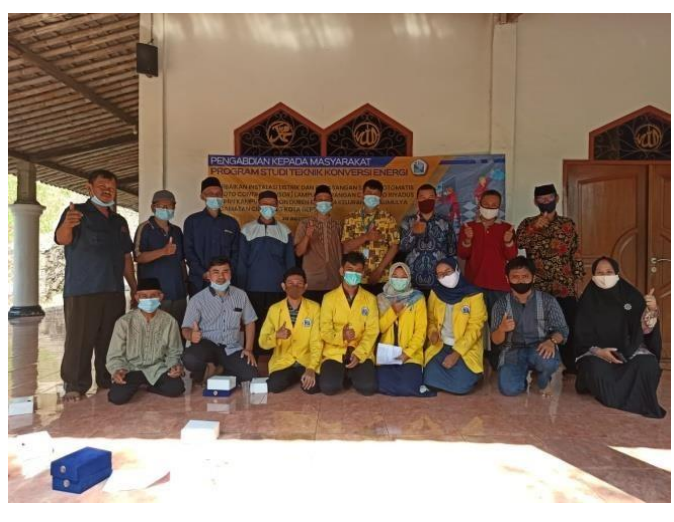

Gambar 2. Foto Bersama

Berdasarkan hasil diskusi dengan pihak RT 03/ RW 04 Kampung Kebon Duren selaku penanggung jawab pengelola Masjid Riyadus Solihin, bahwa memang benar kondisi yang sudah dipaparkan tersebut. Masjid ini perlu untuk diperbaiki instalasi listriknya untuk menunjang kegiatan agama yang akan dilaksanakan oleh warga. 
Oleh sebab itu, tim Dosen Program Studi Teknik Konversi Energi Jurusan Teknik Mesin berinisiatif untuk melakukan perbaikan instalasi listrik di masjid tersebut, serta pemasangan saklar otomatis lampu penerangan dengan photo control sensor. Kegiatan ini bertujuan untuk memberikan solusi atas kendala yang dihadapi mitra saat ini, sehingga diharapkan dengan perbaikan instalasi listrik akan berkontribusi terhadap keamanan dan kerapian instalasi listrik dengan kontinuitas yang terjaga. Selain itu, pada kegiatan ini juga dilakukan pemasangan saklar lampu otomatis yang berfungsi untuk menyalakan dan mematikan lampu penerangan sehingga akan menghemat energi listrik di zaman yang semakin meningkatnya kebutuhan ekonomi masyarakat seperti sekarang ini.

\section{Metode Pelaksanaan}

Kegiatan ini berupa pemberian bantuan Perbaikan Instalasi Listrik dan Pemasangan Saklar Otomatis Photo Control Sensor Lampu Penerangan di Masjid Riyadus Solihin Kampung Kebon Duren RT 03/ RW 04. Kelurahan Kalimulya, Kecamatan Cilodong, Kota Depok.

Metode yang dilaksanakan untuk mencapai tujuan adalah :

1) Memberikan sosilisasi kepada warga RT 03 / RW 04 Kampung Kebon Duren, Kelurahan Kalimulya, Kecamatan Cilodong, Kota Depok tentang pentingnya memelihara keamanan listrik, karena jika hal tersebut diabaikan maka akan berdampak pada keamanan yang lebih krusial.

2) Tim dosen, Perbaikan Instalasi Listrik dan Pemasangan Saklar Otomatis Photo Control Sensor Lampu Penerangan di Masjid Riyadus Solihin Kampung Kebon
Duren RT 03/ RW 04. Kelurahan Kalimulya, Kecamatan Cilodong, Kota Depok.

3) Tahap terakhir yakni pemeliharaan, maksudnya adalah bagaimana ketika batuan sudah diberikan, maka perawatan yang diberikan berupa isntalasi listrik dan Pemasangan Saklar Otomatis Photo Control Sensor Lampu Penerangan harus terpelihara dengan baik.

\section{Hasil Dan Pembahasan}

Tim dalam kegiatan pengabdian adalah dosen Program Studi Konversi Energi, Jurusan Teknik Mesin PNJ yang dibantu oleh mahasiswa, serta warga sebagai steakholder dalam mengatasi permasalahan di wilayahnya. Tugas dosen adalah sebagai perencana yaitu persiapan konsep dan tujuan kegiatan, pelaksana kegiatan, pembuatan laporan kegiatan serta publikasi artikel ilmiah dan artikel popular di media yang menjadi luaran wajib pada kegiatan pengabdian kepada masyarakat. Tugas mahasiswa adalah membantu kelancaran saat hari kegiatan berlangsung dibawah bimbingan dosen dalam berkoordinasi dengan petugas lapangan, melakukan dokumentasi berupa wawancara, foto dan video serta membantu dosen dalam koordinasi untuk publikasi di media.

Perbaikan Instalasi Listrik dan Pemasangan Saklar Otomatis Photo Control Sensor Lampu Penerangan di Masjid Riyadus Solihin Kampung Kebon Duren RT 03/ RW 04. Kelurahan Kalimulya, Kecamatan Cilodong, Kota Depok.

Diharapkan kegiatan ini ada tindak lanjutnya. Artinya ke depan masyarakat yang mitra, yakni masjid Riyadus Solihin dan pengurus serta arga diharapkan mendapatkan pembinaan misalnya mendapatkan pelatihan membuat karya. Dosen Teknik Meisin PNJ berharap kegiatan ini berlangsung 
tidak hanya sekali ini saja, akan tetapi mudah- mudahan ke depan akan direncanakan baik dari kami maupun dari instansi lain untuk mengadakan kegiatan pemberdayaan masyarakat.

\section{Hasil Kuesioner}

Berdasarkan hasil pengukuran di bawah ini, yakni kuesioner yang diberikan kepada beberapa pengurus Masjid Riyadus Solihin umumnya para responden merasa terbantu dengan adanya bantuan isntalasi listrik dan Pemasangan Saklar Otomatis Photo Control Sensor Lampu untukMasjid Riyadus Solihin ini

Untuk pertanyaan pertama, Apakah di Masjd Anda Pernah ada Perbaikan Instalasi Listrik? menjawab tidak. Pertanyaan 2. Apakah di Masjid Anda pernah terjadi kerusakan Listrik? Responden menjawab ya. Pertanyaan Apakah di Masjid Anda pernah melakukan perbaikan masalah kelistrikan? Jawabannya responden ya. Pertanyaan 4 Menurut Anda, apakah bantuan alat intalasi listrik ini dapat bermanfaat untuk Masjid Riyadus Solihin ini? responden menjawab ya. Pertanyaan 5 Apakah panitia yang terlibat dalam kegiatan ini cukup tanggap dalam memberikan dalam mengakomodir kebutuhan Masjid Riyadus Solihin ini? responden menjawab Ya.
Tabel 1. Hasil pengukuran saat kegiatan

\begin{tabular}{|c|l|c|c|}
\hline No & \multicolumn{1}{|c|}{ Pernyataan } & $\begin{array}{c}\text { Jawaban } \\
\text { Ya }\end{array}$ & $\begin{array}{c}\text { Jawaban } \\
\text { Tidak }\end{array}$ \\
\hline 1 & $\begin{array}{l}\text { Apakah di } \\
\text { Masjd Anda } \\
\text { Pernah ada } \\
\text { Perbaikan } \\
\text { Instalasi } \\
\text { Listrik? }\end{array}$ & $\checkmark$ \\
\hline 2 & $\begin{array}{l}\text { Apakah di } \\
\text { Masiid Anda } \\
\text { pernah teriadi } \\
\text { kerusakan } \\
\text { Listrik? }\end{array}$ & $\checkmark$ & \\
\hline 3 & $\begin{array}{l}\text { Apakah di Masiid } \\
\text { Anda pernah } \\
\text { melakukan } \\
\text { perbaikan masalah } \\
\text { kelistrikan? }\end{array}$ & $\checkmark$ & \\
\hline 4 & $\begin{array}{l}\text { Menurut Anda, } \\
\text { apakah bantuan } \\
\text { alat intalasi listrik } \\
\text { ini dapat } \\
\text { bermanfaat untuk } \\
\text { Masjid Riyadus } \\
\text { Solihin ini? }\end{array}$ & $\checkmark$ & \\
\hline 5 & $\begin{array}{l}\text { Apakah panitia } \\
\text { yang terlibat dalam } \\
\text { kegiatan ini cukup } \\
\text { taanggap dalam } \\
\text { mengakomodir } \\
\text { kebutuhan Masiid } \\
\text { Riyadus Solihin } \\
\text { 1n1? }\end{array}$ & $\checkmark$ & \\
\hline
\end{tabular}

\section{Ucapan Terima Kasih}

Ucapan terima kasih kepada semua hak yang mendukung terselenggaranya kegiatan ini mulai dari yang terlibat secara langsung ataupun tidak langsung. Pihak yang terlibat secara langsung yakni para dosen Prodi D-III Teknik Konversi Energi, Jurusan Teknik Mesin, Politeknik Negeri Jakarta yang hadir pada pelaksanaan kegiatan pengabdian, para PLP, admin, para pengurus Masjid Riyadus Solihin Kampung Kebon Duren RT 03/ RW 04 Kelurahan Kalimulya, Kecamatan Cilodong, Kota Depok. Kemudian, kami ucapkan terima kasih juga yakni Direktur Politeknik Negeri Jakarta beserta jajarannya, ketua UP2M PNJ, dan seluruh dosen di Jurusan Teknik Mesin. 


\section{Kesimpulan}

Berdasarkan hasil pelaksanaan pengabdian kepada masyarakat Program Studi Teknik Konversi Energi Tahun 2020 dengan tema dengan judul Perbaikan Instalasi Listrik dan Pemasangan Saklar Otomatis Photo Control Sensor Lampu Penerangan di Masjid Riyadus Solihin Kampung Kebon Duren RT 03/ RW 04. Kelurahan Kalimulya, Kecamatan Cilodong, Kota Depok, terdapat luaran kegiatan yang akan menjadi tanggung jawab tim pengabdian kepada masyarkat disimpulkan bahwa kegiatan ini memberika dampak baik bagi mitra yakni tempat kegiatan peribadatan yang di mana kemanannya harus baik, terutama dalam hal kelistrikan. Karen jika tidak diantisipasi, maka hal-hal yang tidak diinginkan bisa terjadi, misalnya keorselting listrik yang bisa berdampak besar bahkan hingga kebakaran. Aplagi komponen bangunan Masjid Riyadus Solihin masih menggunakan struktur kayu sehingga lebih renatan terjadi kebakaran.

\section{Daftar Pustaka}

[1] BSN, 2000. Persyaratan Umum Instalasi Listrik (PUIL) Kementrian ESDM, 2009. Undang- undang No. 30 Tahun 2009 tentang Ketenagalistrikan Kemenakertrans, 2002.

[2] Kepmenakertrans RI No 75 Tahun 2002 tentang Pemberlakuan Standar Nasional Indonesia (SNI) No SNI04-0225-2000

[3] Mengenai Persyaratan Umum Instalasi Listrik 2000 (PUIL 2000) di Tempat Kerja. Kemenakertrans, 2002.

[4] Keputusan Direktur Jenderal Pembinaan Hubungan Industrial dan Pengawasan Ketenagakerjaan No 311 Tahun 2002 tentang Sertifikasi Kompetensi Keselamatan dan Kesehatan Kerja Teknisi Listrik.

[5] Keputusan Bersama Menteri Tenaga Kerja dan Menteri Pekerjaan Umum RI No 174 Tahun 1986 No 104/KPTS/1986 tentang Keselamatan dan Kesehatan Kerja pada Tempat Kegiatan Konstruksi. Margiono, 2014. Instalasi Listrik Bangunan Sederhana. 